\title{
Protective Effect of Hydrogen Peroxide against Paraquat Toxicity in Young Pea Plants: Possible Role of Endogenous Polyamines
}

\author{
Irina Moskova, Dessislava Todorova*, Vera Alexieva, Iskren Segiev \\ Institute of Plant Physiology and Genetics, Bulgarian Academy of Sciences, Sofia, Bulgaria \\ Email: ${ }^{*}$ dessita@bio21.bas.bg
}

Received 1 September 2014; revised 7 October 2014; accepted 3 November 2014

Copyright (C) 2014 by authors and Scientific Research Publishing Inc.

This work is licensed under the Creative Commons Attribution International License (CC BY). http://creativecommons.org/licenses/by/4.0/

(c) (i) Open Access

\begin{abstract}
Young pea plants grown as a water culture were sprayed with hydrogen peroxide and $24 \mathrm{~h}$ later were treated with the herbicide paraquat. The effects of paraquat and $\mathrm{H}_{2} \mathrm{O}_{2}$ treatment were investigated on the endogenous concentrations of free proline, and free and conjugated putrescine, spermidine and spermine. Application of $P Q$ increased the free proline and Put, and decreased conjugated and bound polyamines. The results clearly demonstrate the oxidative damages provoked by $P Q$ application. Single treatment with $\mathrm{H}_{2} \mathrm{O}_{2}$ provoked considerable decrease in the free fraction of the three PAs studied $2 \mathrm{~h}$ after light exposition, but caused an increase in their respective conjugated fractions. Data suggest that PA changes after $\mathrm{H}_{2} \mathrm{O}_{2}$ treatment are due to conversion from free to conjugated form. Three hours later free PAs in $\mathrm{H}_{2} \mathrm{O}_{2}$ treated-plants reached control levels; however the conjugated remained higher than the control. No alterations were detected in proline concentration after $\mathrm{H}_{2} \mathrm{O}_{2}$ treatment. Pretreatment with $\mathrm{H}_{2} \mathrm{O}_{2}$ activated some component of the plant protection mechanisms by causing an alteration in free/conjugated PAs ratio in plants subsequently subjected to $P Q$ treatment. Data concerning $P A$ and proline concentrations in plants treated with both compounds supposed that $\mathrm{H}_{2} \mathrm{O}_{2}$ shows a protective role against $P Q$ and improves the plant tolerance to the oxidative stress generated by paraquat.
\end{abstract}

\section{Keywords}

Hydrogen Peroxide, Paraquat, Pisum sativum, Polyamines, Proline

\footnotetext{
"Corresponding author.
}

How to cite this paper: Moskova, I., Todorova, D., Alexieva, V. and Segiev, I. (2014) Protective Effect of Hydrogen Peroxide against Paraquat Toxicity in Young Pea Plants: Possible Role of Endogenous Polyamines. American Journal of Plant Sciences, 5, 3408-3416. http://dx.doi.org/10.4236/ajps.2014.522356 


\section{Introduction}

Polyamines (PAs) are low-weight organic molecules, widely distributed in higher and lower plants, and the PAs common for all plant species are putrescine (Put), spermidine (Spd) and spermine (Spm). They occur as free molecules, but can also be conjugated with small molecules such as phenolic acids or bound to macromolecules like nucleic acids and proteins for their polycationic nature [1]. Polyamines play a key role in growth, development and reproduction of plants [1] [2]. Another important function of PAs is attributed to plant protection against different stresses [3] [4], including herbicides [5]-[9]. PAs are involved in the control of various cellular functions: scavenging of free radicals, antioxidant activity, and modulation of plant stress tolerance [3] [4]. Additionally, concept exists that conjugation of polyamines could be considered as a regulatory mechanism of the free PA pool [1].

Paraquat (PQ) is a bipyridilium contact herbicide which is diverting electrons from Photosystem I, and thus forming bipyridilium radicals by reaction with oxygen are producing superoxide radicals followed by chain reactions leading to generation of other reactive forms of oxygen. Paraquat is inhibiting the $\mathrm{CO}_{2}$ fixation in plants, but its rapid herbicide action is attributed mainly to the generation of active oxygen species (AOS) [10], and thus the biomembranes are subjected to a free radical attack [11]. The double-bonds of the biomembrane's unsaturated fatty acids are primary targets for AOS, which initiate chain reactions of lipid peroxidation followed by destruction and disorder in the normal membrane permeability [7] [12].

In our previous investigations [13]-[15], we have established that pre-treatment of young pea plants with low concentration of hydrogen peroxide decreased the damages caused by subsequently applied PQ. Here, we report the changes in plant polyamine and proline concentrations in pea treated with $\mathrm{H}_{2} \mathrm{O}_{2}$ and PQ. The results presented in this study suggest that preliminary application of $\mathrm{H}_{2} \mathrm{O}_{2}$ on pea plants subsequently treated with PQ alleviates the toxic effects of the herbicide by influencing endogenous polyamine concentrations.

\section{Materials and Methods}

\subsection{Plant Material, Growth Conditions and Treatment}

Seedlings of Pisum sativum L. were grown on a half-strength Hoagland-Arnon nutrition medium in a growth chamber under the following conditions- $12 / 12 \mathrm{~h}$ photoperiod; light intensity $70 \mu \mathrm{mol} \cdot \mathrm{m}^{2} \cdot \mathrm{s}^{-1}$; temperature $25^{\circ} \mathrm{C}$ $\pm 1^{\circ} \mathrm{C}$. Ten-day-old seedlings were sprayed with an aqueous solution of $\mathrm{H}_{2} \mathrm{O}_{2}(2.5 \mathrm{mM})$ containing $0.1 \%$ Tween 80 , and $24 \mathrm{~h}$ later, part of the plants were sprayed with $0.2 \mathrm{mM}$ aqueous solution of paraquat containing $0.1 \%$ Tween 80 . The control plants were sprayed with water containing $0.1 \%$ Tween 80 at each chemical application stage. Paraquat treatment was carried out after the end of the light phase in the photoperiod cycle, thus giving a $12 \mathrm{~h}$ of incubation period during which the herbicide effects are usually weak [16].

Samples for measurement were taken $2 \mathrm{~h}$ after the beginning of illumination when there were still no visible herbicide effects, and $5 \mathrm{~h}$ after beginning of illumination when the first visible symptoms of injury were observed.

Biochemical analyses were carried out on fresh plant material derived from $2^{\text {nd }}$ leaves which was immediately extracted and assayed according to the appropriate methods listed below.

\subsection{Polyamine Extraction and Determination}

Plant material (approximately $200 \mathrm{mg}$ ) was ground in mortar with pestle in $2 \mathrm{ml}$ of trichloroacetic acid (TCA). After centrifugation $(30 \mathrm{~min}, 15,000 \times \mathrm{g}$ ) the supernatant and pellet were used for further analyses.

The direct dansylation method was used to determine the free Put, Spd and Spm levels [17]. Conjugated PAs were measured in acid-hydrolyzed supernatants as TCA-soluble bound PAs, and bound PAs in acid-hydrolyzed pellets as TCA-insoluble bound polyamines, according to [18]. The three fractions of PAs were separated using TLC precoated plates of Silicagel G 60 (Merck) in a cyclohexane:ethylacetate (3:2, v/v) solvent system. Spots, visualised under UV light, were scraped off and eluted in $2 \mathrm{ml}$ anhydrous acetone. Fluorescence was measured (excitation $360 \mathrm{~nm}$, emission $505.5 \mathrm{~nm}$ ) and the results were compared with dansylated PA standards loaded on the same TLC plate and treated as extracted samples. The dansyl chloride and Put, Spd and Spm standards were purchased from Sigma-Aldrich. 


\subsection{Determination of Proline}

The proline concentration was assayed by the method described by [19]. Approximately $0.3 \mathrm{~g}$ of plant material was homogenized in $6 \mathrm{ml}$ of aqueous sulfosalicylic acid and homogenate was centrifuged at 19,000 g for 30 min. Two $\mathrm{ml}$ of extracted solution was reacted with acid ninhydrin and $2 \mathrm{ml}$ of glacial acetic acid in a test tube for 1 hour at $100^{\circ} \mathrm{C}$, and the reaction terminated in an ice bath. The reaction mixture was extracted with $4 \mathrm{ml}$ toluene, mixed vigorously with a test tube stirrer for 15 - $20 \mathrm{sec}$. The chromophore containing toluene was aspirated from the aqueous phase, warmed to room temperature and the absorbance read at $520 \mathrm{~nm}$ using toluene for a blank. The proline concentration was determined from a standard curve prepared according the same procedure with known amounts of proline.

\subsection{Statistical Procedures}

All experiments were repeated three times with three to five replications. The results reported in the figures and table are means of the values with standard error (SE). The different letters in figures and table indicate significant differences between treatments at $\mathrm{P}<0.05$.

\section{Results}

A decrease of free proline content was detected $2 \mathrm{~h}$ after application of $\mathrm{H}_{2} \mathrm{O}_{2}$ (by 28\%), while 3 hours later its content was near the control level (Table 1 ).

Initially (2 $\mathrm{h}$ after illumination) a slight decrease of free proline was detected by PQ application. However, PQ application caused significant increase of free proline concentration (by 52\%) $5 \mathrm{~h}$ after starting of illumination. Free proline was not altered significantly in plants treated with both $\mathrm{H}_{2} \mathrm{O}_{2}$ and $\mathrm{PQ}$ as compared to relative controls.

At the first measurement ( $2 \mathrm{~h}$ after starting of illumination) the application of $\mathrm{H}_{2} \mathrm{O}_{2}$ led to considerable decrease of free Put, accompanied by significant increase of conjugated and bound form (Figure 1). Three hours later most significant changes were observed in conjugated Put, which was still elevated in relation to the control. Alone applied PQ caused amplification of free Put $2 \mathrm{~h}$ after beginning of illumination. However, no considerable changes in both bound and conjugated fractions were observed after PQ treatment. At the second measurement, free Put was still elevated, but conjugated form was decreased by PQ application. Pre-treatment with $\mathrm{H}_{2} \mathrm{O}_{2}$ led to decrease of free Put as compared to alone PQ. The concentrations of both bound and conjugated Put fractions were comparable with the respective control.

The changes of free, conjugated, and bound Spd levels (Figure 2) in $\mathrm{H}_{2} \mathrm{O}_{2}$-treated plants were similar to those of Put at both measurements. Treatment with PQ caused insignificant alterations of free Spd, and slight increase of bound Spd at both measurement points. Initially PQ increased conjugated Spd, but 3 hours later a decrease was observed. In pea plants pre-treated with $\mathrm{H}_{2} \mathrm{O}_{2}$ the conjugated and bound fractions of Spd after $2 \mathrm{~h}$ of illumination were slightly above than the respective control, while free Spd was significant decreased. At second measurement point, all three Spd fractions reached the control values.

Changes of free Spm (Figure 3(A)) were similar to free Spd (Figure 2(A)). At second measurement only combined treatment with both compounds showed lower Spm concentration than those observed in other variants. Initially $\mathrm{H}_{2} \mathrm{O}_{2}$ did not provoke considerable enhance of conjugated Spm but three hours later this fraction was significantly increased. In distinct PQ led to decrease of conjugated Spm especially at second measurement.

Table 1. Free proline concentration in $2^{\text {nd }}$ leaves of pea plants treated with $\mathrm{H}_{2} \mathrm{O}_{2}$ and paraquat. Data are mean values \pm SE. Different letters indicate significant differences between treatments at $\mathrm{P}<0.05$.

\begin{tabular}{crc}
\hline Proline $[\mu \mathrm{mol} / \mathrm{gFW}]$ & $2 \mathrm{~h}$ after illumination & $5 \mathrm{~h}$ after illumination \\
\hline Control & $2.3422^{\mathrm{a}} \pm 0.067$ & $1.9900^{\mathrm{a}} \pm 0.047$ \\
$\mathrm{H}_{2} \mathrm{O}_{2}$ & $1.6785^{\mathrm{c}} \pm 0.018$ & $1.9273^{\mathrm{a}} \pm 0.009$ \\
$\mathrm{PQ}$ & $1.9065^{\mathrm{b}} \pm 0.102$ & $3.0169^{\mathrm{b}} \pm 0.142$ \\
$\mathrm{H}_{2} \mathrm{O}_{2}+\mathrm{PQ}$ & $2.2442^{\mathrm{a}} \pm 0.011$ & $2.0608^{\mathrm{a}} \pm 0.206$ \\
\hline
\end{tabular}




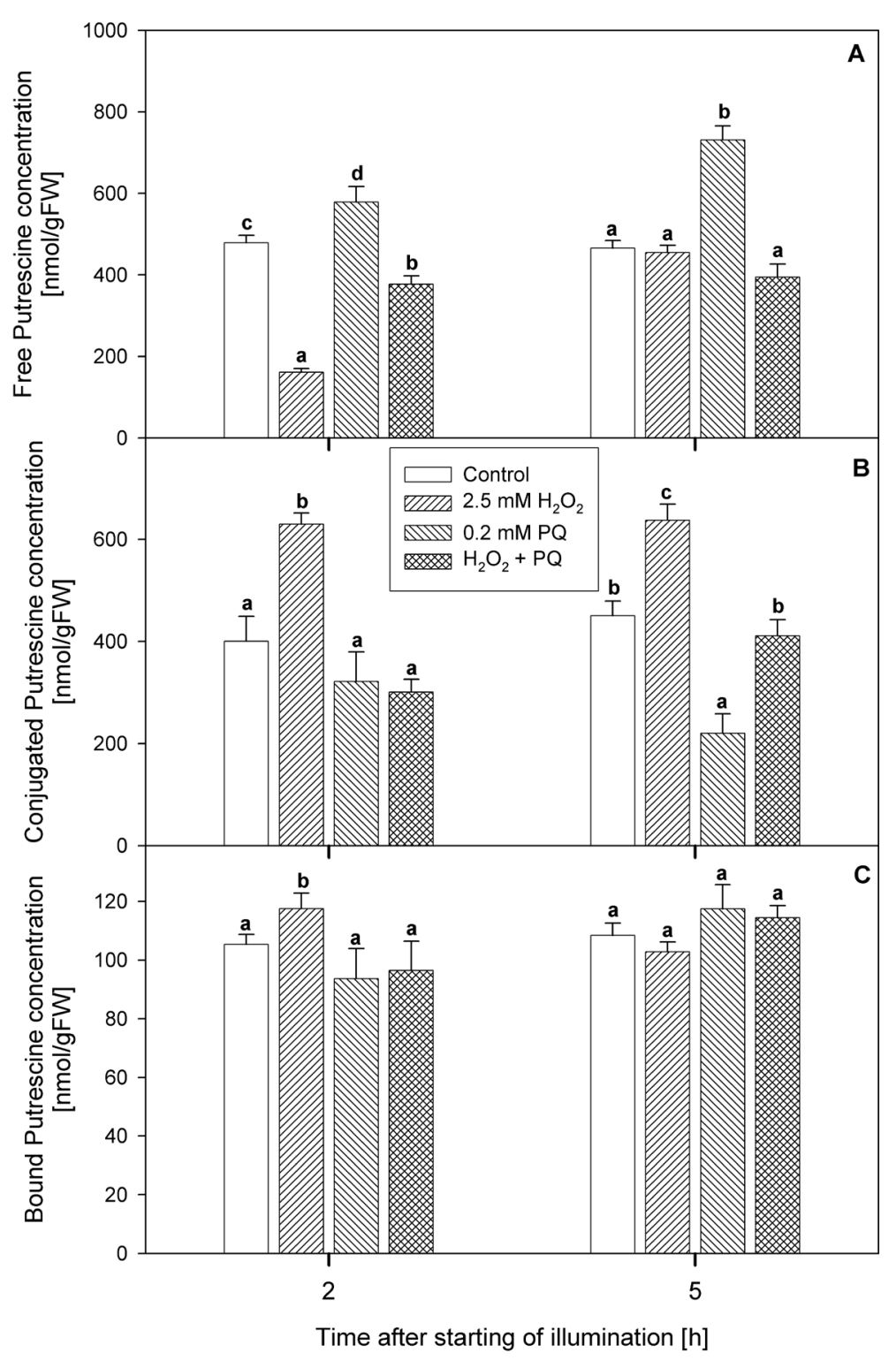

Figure 1. Free (A), conjugated (B), and bound (C) putrescine concentration in $2^{\text {nd }}$ leaves of pea plants treated with $\mathrm{H}_{2} \mathrm{O}_{2}$ and paraquat. Data are mean values \pm SE. Different letters indicate significant differences between treatments at $\mathrm{P}<0.05$.

At first combined treatment caused rise of this Spm form but at second measurement an opposite tendency was observed. Two hours after starting of illumination, bound Spm was increased by $\mathrm{H}_{2} \mathrm{O}_{2}$ application, while in both variants with PQ treatment it was slightly below the control. Three hours later, no significant differences between variants were detected in relation to this Spm fraction.

\section{Discussion}

Proline is accumulated in plant tissues because of various stresses. The increased proline content is believed to play a role as a part of the endogenous defense system [20] [21], but some authors discussed its augmentation as a stress marker [19] [22]. In our model system, an increase of free proline was observed only in PQ-treated plants (Table 1). The amount of proline in plants preliminary sprayed with $\mathrm{H}_{2} \mathrm{O}_{2}$ was comparable with the relative controls. In our opinion, the augmentation of proline in PQ-treated plants could be considered as a stress 


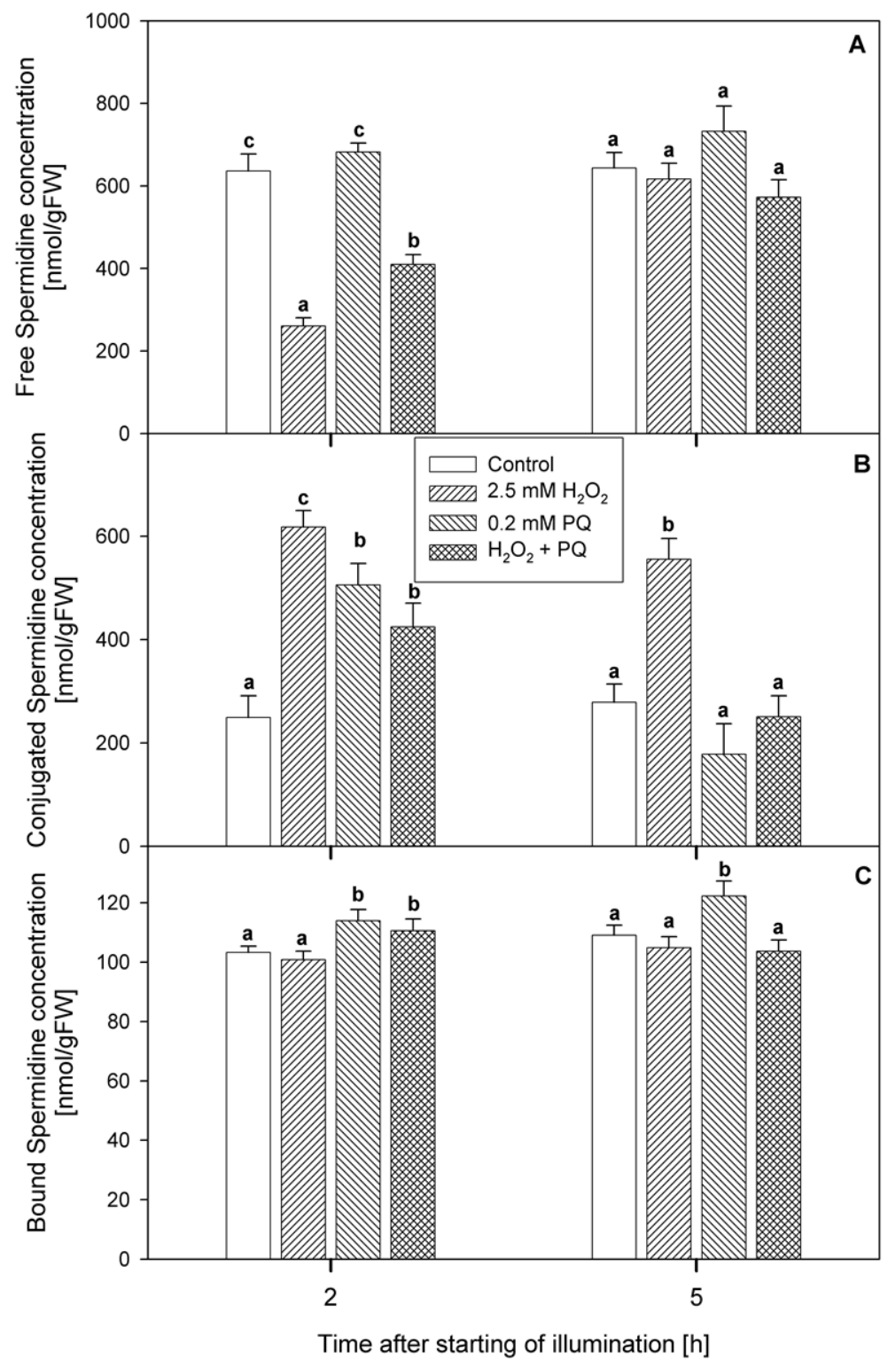

Figure 2. Free (A), conjugated (B), and bound (B) spermidine concentration in $2^{\text {nd }}$ leaves of pea plants treated with $\mathrm{H}_{2} \mathrm{O}_{2}$ and paraquat. Data are mean values \pm SE. Different letters indicate significant differences between treatments at $\mathrm{P}<0.05$.

marker. The lack of change of proline concentration in $\mathrm{H}_{2} \mathrm{O}_{2}$ pre-treated plants and subsequently treated with PQ, supports the suggestion of the protective role of hydrogen peroxide against PQ action.

Data presented in Figures 1-3 indicate that PAs are affected in a different manner by the treatments. The results show that most important changes of endogenous PAs were in relation to free Put, Spd and Spm at first measurement point as well as in the conjugated PAs at both measurements.

The elevation of Put because of different stresses is widely discussed in the literature. Most often the increased free Put gives an indication for the stress impact [8]. On the other hand, the enhanced Put is supposed to play a role as a tool of the endogenous defense system but this role was attributed mainly to the bound and conjugated Put [3]. Single application of PQ led to enhanced free Put (Figure 1(A)). This was not unexpected result since it is well known that PQ provoked an oxidative stress [16] and free Put in this case could be assumed as a stress marker. Conjugated PAs is considered to be more effective fraction as radical scavengers of AOS than the 


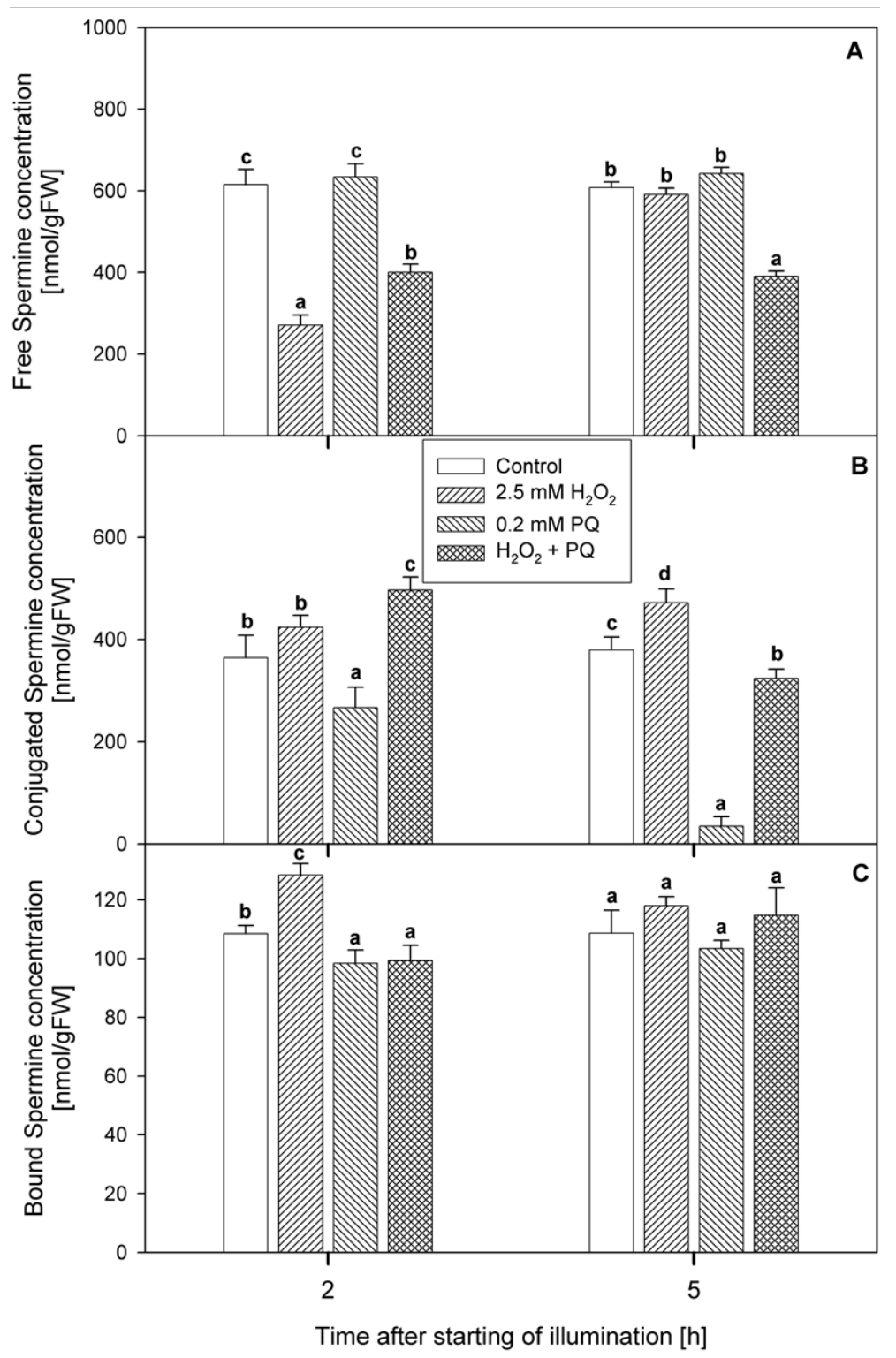

Figure 3. Free (A), conjugated (B), and bound (B) spermine concentration in $2^{\text {nd }}$ leaves of pea plants treated with $\mathrm{H}_{2} \mathrm{O}_{2}$ and paraquat. Data are mean values \pm SE. Different letters indicate significant differences between treatments at $\mathrm{P}$ $<0.05$.

free form [1] [23]. On the other hand, PQ led to decreased conjugated PAs, and then PAs concentrations continued to decline till second measurement but without relevant liberation of free PAs. Most probably, PQ caused disturbance of cellular PAs balance, which led to lower possibilities for scavenging of AOS since reduced conjugated PAs and this way plants had worse potential for surviving.

Treatment with $\mathrm{H}_{2} \mathrm{O}_{2}$ predominantly led to a decline of the free PAs fractions accompanied by a significant augmentation of conjugated fraction. Similar results were obtained for Spd and Spm at first measurement in plants treated with $\mathrm{H}_{2} \mathrm{O}_{2}$ and $\mathrm{PQ}$. A possible reason for the increment of conjugated form accompanied by decrease of the respective free fraction could be the conjugation with low-molecular weight substances. It was established that the conjugated PAs have scavenging properties comparable to those of known efficient radical scavengers, e.g. ascorbate [23]. Additionally, it have to be pointed that three hours later free $\mathrm{PAs}$ in $\mathrm{H}_{2} \mathrm{O}_{2}$ treated plants reached control levels, however conjugated remained higher than the control. Our results are in consent 
with hypothesis that conjugated PAs play important role for increasing of the plant stress tolerance [1] [3] [23] [24].

Despite of the fact that $\mathrm{H}_{2} \mathrm{O}_{2}$ is acknowledged as a signal for activation of plant defense system under various stresses the mechanism by which it caused protective effect on pretreated plants remained unclear [25]-[27]. It was established that the pretreatment with $\mathrm{H}_{2} \mathrm{O}_{2}$ increased the activities of several antioxidant enzymes and/or the levels of some antioxidants such as glutathione [14] [27]-[30]. It is well known that conjugation of PAs with phenolic acids is an enzymatic process [31] [32]. Therefore, it could be proposed that $\mathrm{H}_{2} \mathrm{O}_{2}$ renders similar effect on the enzymes involved in PAs conjugations. Moreover, the enhanced by $\mathrm{H}_{2} \mathrm{O}_{2}$ conjugated PAs concentrations well correlated with results from our previous studies where we have observed that $\mathrm{H}_{2} \mathrm{O}_{2}$ pre-treatment decreased the damages caused by PQ [14]. Based on the results presented here it could be proposed that $\mathrm{H}_{2} \mathrm{O}_{2}$ activated some component of the plant protection mechanisms by causing an alteration in free/conjugated PAs ratio. Thus, the plants subsequently treated with PQ had higher potential for surviving [13].

\section{Conclusion}

In our previous study, we have established that $\mathrm{H}_{2} \mathrm{O}_{2}$ pretreatment prevented the inhibition of photosynthesis, and chlorophyll loss provoked by PQ, and the plant showed higher rates of survival [13]. Further, we showed that the negative effect of $\mathrm{PQ}$, which was considerable in relation to content of ascorbic acid and glutathione, was significantly eliminated by $\mathrm{H}_{2} \mathrm{O}_{2}$ pretreatment. The application of $\mathrm{H}_{2} \mathrm{O}_{2}$ prior to PQ treatment induced the activities of defense enzymes and especially of ascorbate peroxidase [14]. More recently, we have presented the changes of leaf morphological and histological characteristics provoked by PQ application and the protective role of $\mathrm{H}_{2} \mathrm{O}_{2}$ pretreatment was attributed to alteration of cell wall architecture and structure [15]. Additionally, we have established that PQ destroyed the energy transfer in and between photosystems and reduced the functional antennae size of both PSs, while pretreatment with $\mathrm{H}_{2} \mathrm{O}_{2}$ reduced to some extent the PQ mediated oxidative stress on the photosynthetic light reactions at the level of thylakoid membrane [33]. The present research further supports the suggestion that pretreatment with $\mathrm{H}_{2} \mathrm{O}_{2}$ triggers different defense mechanisms and the change of free/conjugated PAs ratio is one of them.

\section{Acknowledgements}

This work was supported by the grant №BG051PO001-3.3.06-0025, financed by the European Social Fund and Operational Programme Human Resources Development (2007-2013) and co-financed by Bulgarian Ministry of Education and Science.

\section{References}

[1] Martin-Tanguy, J. (2001) Metabolism and Function of Polyamines in Plants: Recent Development (New Approaches). Plant Growth Regulation, 100, 675-688.

[2] Kakkar, R.K., Nagar, P.K., Ahuja, P.S. and Rai, V.K. (2000) Polyamines and Plant Morphogenesis. Biologia Plantarum, 43, 1-11. http://dx.doi.org/10.1023/A:1026582308902

[3] Bouchereau, A., Aziz, A., Larher, F. and Martin-Tanguy, J. (1999) Polyamines and Environmental Challenges: Recent Development. Plant Science, 140, 103-125. http://dx.doi.org/10.1016/S0168-9452(98)00218-0

[4] Groppa, M.D. and Benavides, M.P. (2008) Polyamines and Abiotic Stress: Recent Advances. Amino Acids, 1, 35-45. http://dx.doi.org/10.1007/s00726-007-0501-8

[5] Zheleva, D., Alexieva, V. and Karanov, E. (1993) Influence of Atrazine on Free and Bound Polyamine Levels in Pea Plants. Journal of Plant Physiology, 141, 281-285. http://dx.doi.org/10.1016/S0176-1617(11)81735-9

[6] Kurepa, J., Smalle, J., Van Montagu, M. and Inze, D. (1998) Oxidative Stress Tolerance and Longevity in Arabidopsis: The Late-Flowering Mutant Gigantea Is Tolerant to Paraquat. Plant Journal, 14, 759-764. http://dx.doi.org/10.1046/j.1365-313x.1998.00168.x

[7] Szigeti, Z., Racz, I. and Lasztity, D. (2001) Paraquat Resistance of Weeds-The Case of Conyza canadensis (L.) Cronq. Zeitschrift für Naturforschung, 56c, 319-328.

[8] Szigeti, Z. and Lehoczki, E. (2003) A Review of Physiological and Biochemical Aspects of Resistance to Atrazine and Paraquat in Hungarian Weeds. Pest Management Science, 59, 451-458. http://dx.doi.org/10.1002/ps.647

[9] Soar, C.J., Preston, C., Karotam, J. and Powles, S.B. (2004) Polyamines Can Inhibit Paraquat Toxicity and Transloca- 
tion in the Broadleaf Weed Arctotheca calendula. Pesticide Biochemistry and Physiology, 80, 94-105. http://dx.doi.org/10.1016/j.pestbp.2004.07.002

[10] Harvey, B. and Fraser, T.W. (1980) Paraquat Tolerant and Susceptible Perennial Rye Grasses: Effects of Paraquat Treatment on Carbon Dioxide Uptake and Ultrastucture of Photosynthetic Cells. Plant, Cell and Environment, 3, 107117.

[11] Farrington, J.A., Ebert, M., Land, E.J. and Fletcher, K. (1973) Bipyridylium Quaternary Salts and Related Compounds. V. Pulse Radiolysis Studies of the Reaction of Paraquat Radical with Oxygen. Implication for the Mode of Action of Bipyridyl Herbicides. Biochimica et Biophysica Acta-Bioenergetics, 314, 372-381. http://dx.doi.org/10.1016/0005-2728(73)90121-7

[12] Cobb, A. (1992) Herbicides and Plant Physiology. Chapman \& Hall, London.

[13] Moskova, I., Todorova, D., Alexieva, V. and Sergiev, I. (2007) Hydrogen Peroxide Pretreatment Alleviates Paraquat Injuries in Pea (Pisum sativum L.). Comptes rendus de l'Académie bulgare des Sciences, 60, 1101-1106.

[14] Moskova, I., Todorova, D., Alexieva, V., Ivanov, S. and Sergiev, I. (2009) Effect of Exogenous Hydrogen Peroxide on Enzymatic and Nonenzymatic Antioxidants in Leaves of Young Pea Plants Treated with Paraquat. Plant Growth Regulation, 57, 193-202. http://dx.doi.org/10.1007/s10725-008-9336-X

[15] Moskova, I., Todorova, D., Alexieva, V. and Sergiev, I. (2011) Leaf Morphology and Histology Changes of Pea Plants Treated with Hydrogen Peroxide and Paraquat. Comptes rendus de l'Academie bulgare des Sciences, 64, 1695-1700.

[16] Chang, C.J. and Kao, C.H. (1997) Paraquat Toxicity Is Reduced by Polyamines in Rice Leaves. Plant Growth Regulation, 22, 163-168. http://dx.doi.org/10.1023/A:1005890312557

[17] Smith, T. and Best, G. (1977) Polyamines in Barley Seedlings. Phytochemistry, 16, 841-843. http://dx.doi.org/10.1016/S0031-9422(00)86676-5

[18] Torrigiani, P., Altamura, M., Copitani, F., Serafini-Fracasini, D. and Bagni, N. (1989) De Novo Root Formation in Thin Cell Layers of Tobacco: Changes in Free and Bound Polyamines. Physiologia Plantarum, 77, 294-301. http://dx.doi.org/10.1111/j.1399-3054.1989.tb05644.x

[19] Bates, L.S., Waldern, R.P. and Teare, I.D. (1973) Rapid Determination of Free Proline for Water-Stress Studies. Plant and Soil, 39, 205-207. http://dx.doi.org/10.1007/BF00018060

[20] Pandey, R. and Ganapathy, P. (1985) The Proline Enigma: NaCl Tolerant and NaCl Sensitive Callus Lines of Cicer arietinum. Plant Science, 40, 13-17. http://dx.doi.org/10.1016/0168-9452(85)90157-8

[21] Rai, V.K. (2002) Role of Amino Acids in Plant Responses to Stresses. Biologia Plantarum, 45, 481-487. http://dx.doi.org/10.1023/A:1022308229759

[22] Todorova, D., Moskova, I., Sergiev, I., Alexieva, V. and Mapelli, S. (2008) Changes in Endogenous Polyamines and Some Stress Markers Content Induced by Drought, 4PU-30 and Abscisic Acid in Wheat Plants. In: Khan, N. and Singh, S., Eds., Abiotic Stress and Plant Responses, I.K. International Publishing House Pvt. Ltd., New Delhi, 205-215.

[23] Langebartels, C., Kerner, K., Leonardi, S., Schraudner, M., Trost, M., Heller, W. and Sandermann, H. (1991) Biochemical Plant Responses to Ozone. 1. Differential Induction of Polyamine and Ethylene Biosynthesis in Tobacco. Plant Physiology, 95, 882-889. http://dx.doi.org/10.1104/pp.95.3.882

[24] Kasukabe, Y., He, L., Nada, K., Misawa, S., Ihara, I. and Tachibana, S. (2004) Overexpression of Spermidine Synthase Enhances Tolerance to Multiple Environmental Stresses and Up-Regulates the Expression of Various Stress-Regulated Genes in Transgenic Arabidopsis thaliana. Plant and Cell Physiology, 45, 712-722. http://dx.doi.org/10.1093/pcp/pch083

[25] Doke, N., Miura, Y., Leandro, M.S. and Kawakita, K. (1994) Involvement of Superoxide in Signal Transduction: Responses to Attack by Pathogens, Physical and Chemical Shocks, and UV Radiation. In: Foyer, C.H. and Mullineaux, P.M., Eds., Causes of Photooxidative Stress and Amelioration of Defence Systems in Plants, CRC Press, Boca Raton, 177-197.

[26] Prasad, T.K., Anderson, M.D., Martin, B.A. and Stewart, C.R. (1994) Evidence for Chilling-Induced Oxidative Stress in Maize Seedlings and a Regulatory Role for Hydrogen Peroxide. Plant Cell, 6, 65-74. http://dx.doi.org/10.1105/tpc.6.1.65

[27] Foyer, C., Lorez-Delgado, H., Dat, J. and Scott, I. (1997) Hydrogen Peroxide- and Glutathione-Associated Mechanisms of Acclimatory Stress Tolerance and Signaling. Physiologia Plantarum, 100, 241-254. http://dx.doi.org/10.1111/j.1399-3054.1997.tb04780.x

[28] Karpinski, S., Reynolds, H., Karpinska, B., Wingsle, G., Creissen, G. and Mullineaux, P. (1999) Systematic Signaling and Acclimation in Response to Excess Excitation Energy in Arabidopsis. Science, 284, 654-657. http://dx.doi.org/10.1126/science.284.5414.654

[29] Gechev, T., Willekens, H., Van Montagu, M., Inze, D., Van Camp, W., Toneva, V. and Minkov, I. (2003) Different 
Responses of Tobacco Antioxidant Enzymes to Light and Chilling Stress. Journal of Plant Physiology, 160, 509-515. http://dx.doi.org/10.1078/0176-1617-00753

[30] Yu, C.W., Murphy, T., Sung, W.W. and Lin, C.H. (2002) $\mathrm{H}_{2} \mathrm{O}_{2}$ Treatment Induces Glutathione Accumulation and Chilling Tolerance in Mung Bean. Functional Plant Biology, 29, 1081-1087. http://dx.doi.org/10.1071/PP01264

[31] Legaz, M.E., De Armas, R., Pinon, D. and Vicente, C. (1998) Relationships between Phenolics-Conjugated Polyamines and Sensitivity of Sugarcane to Smut (Ustilago scitaminea). Journal of Experimental Botany, 49, 1723-1728. http://dx.doi.org/10.1093/jxb/49.327.1723

[32] Bagni, N. and Tassoni, A. (2001) Biosynthesis, Oxidation and Conjugation of Aliphatic Polyamines in Higher Plants. Amino Acid, 20, 301-317. http://dx.doi.org/10.1007/s007260170046

[33] Stoichev, S., Tsonova, I., Moskova, I., Krumova, S. and Busheva, M. (2014) Exogenous $\mathrm{H}_{2} \mathrm{O}_{2}$ Partially Prevents the Paraquat Induced Oxidative Stress in Thylakoid Membranes. Comptes rendus de l'Acádemie bulgare des Sciences, 67, 237-242. 
Scientific Research Publishing (SCIRP) is one of the largest Open Access journal publishers. It is currently publishing more than 200 open access, online, peer-reviewed journals covering a wide range of academic disciplines. SCIRP serves the worldwide academic communities and contributes to the progress and application of science with its publication.

Other selected journals from SCIRP are listed as below. Submit your manuscript to us via either submit@scirp.org or Online Submission Portal.
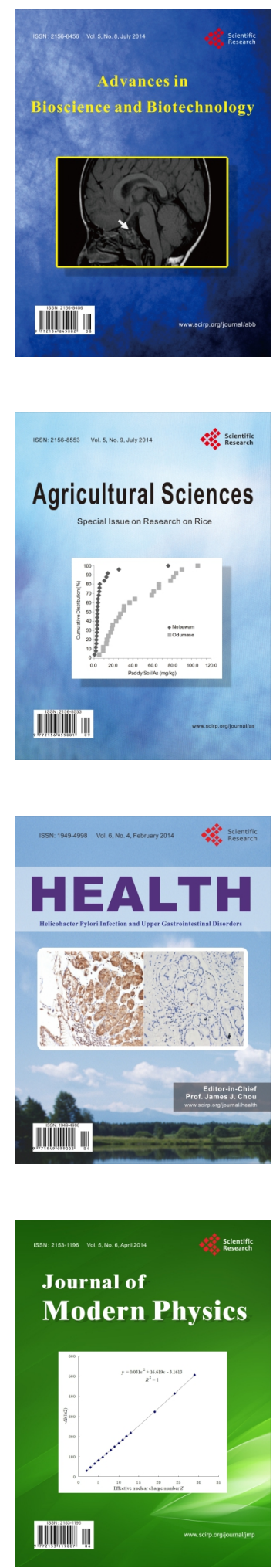
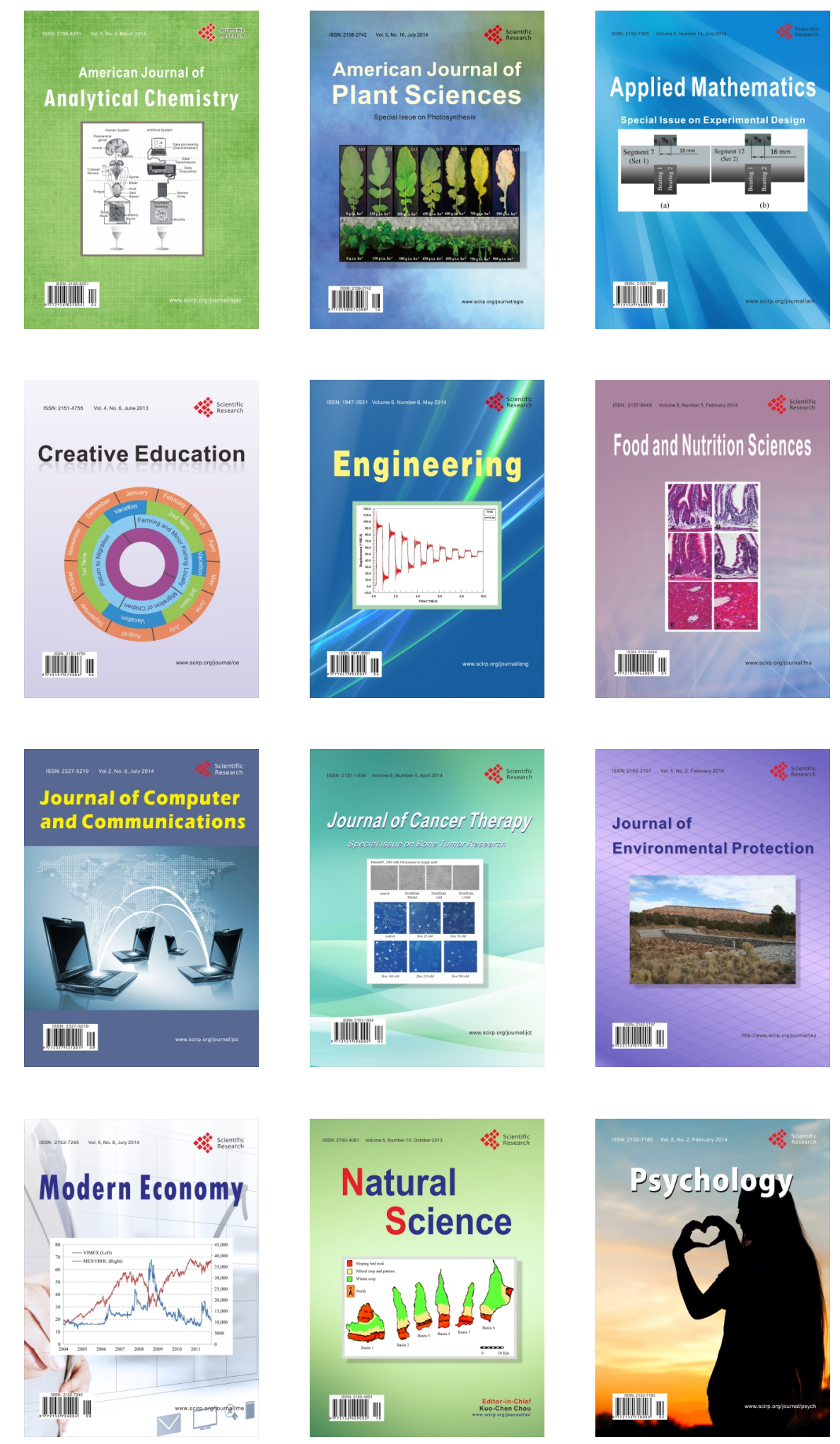